\title{
Faktor-faktor yang Mempengaruhi Dinamika Kelompok dan Hubungannya dengan Kelas Kemampuan Kelompok Tani di Desa Pulokencana Kabupaten Serang
}

\section{Factors Affecting Farmers Group Dynamics in Relation with Category of Farmers Group Capabilities in Pulokencana Village District of Serang}

\author{
Inta P.N. Damanik ${ }^{1}$ \\ ${ }^{1}$ Staf Pengajar Fakultas Pertanian Universitas Pattimura Ambon, \\ Jln. Dr. Tamaela - Ambon
}

\begin{abstract}
Group dynamics is an important factor in the development offarmers' groups. The aims of this study is to know the differences between of farmer group dynamics which includes highest class with lowest class. The results showed that there was no relationship between class ability of farmer groups with the level of group dynamics. Capability class of farmers group evaluation which undertaken in the village Pulokencana only based on an assessment of the head of farmers group and age of group only. The fact that Banjar Tani group is more dynamic than the Banyu Mukti group, but the class between that two groups very different, Banyu Mukti is Main class while the Banjar Tani is Beginners class. Factors that affect the group dynamics are land area, family size, age of group leader and age of farmer groups, and the reception of members of the group leader: In addition, the eight elements of group dynamics, only two elements that do not affect the group dynamics, namely the element of group objective and group pressure. Meanwhile, the six elements that influence group dynamics, the task function has the strongest influence on the dynamics of farmer groups.
\end{abstract}

Keywords: farmer group, group dynamics

\begin{abstract}
Abstrak
Dinamika kelompok merupakan faktor penting dalam perkembangan suatu kelompok tani, karena itu penilaian terhadap dinamika suatu kelompok perlu dilakukan.Penelitian ini bertujuan untuk mengetahui perbedaan dinamika kelompok antara kelompok tani yang termasuk kelas Utama dengan kelompok tani kelas Pemula.Hasil penelitian menunjukkan bahwa tidak ada keterkaitan antara kelas kemampuan kelompok tani dengan tingkat dinamika kelompok tersebut.Penilaian kelas kemampuan kelompok yang dilakukan di Desa Pulokencana hanya didasarkan atas penilaian terhadap ketua kelompok semata dan umur kelompok. Dengan demikian, meskipun kenyataannya kelompok tani Banjar Tani lebih dinamis dibandingkan kelompok Banyu Mukti, namun kelas kemampuan antara keduanya sangat berbeda, yaitu Banyu Mukti termasuk kelas Utama sedangkan Banjar Tani termasuk kelas Pemula. Faktor-faktor yang mempengaruhi dinamika kelompok adalah faktor luas lahan dan jumlah tanggungan, umur ketua dan umur kelompok tani, serta penerimaan anggota terhadap pemimpin kelompok. Disamping itu, dari delapan unsur dinamika kelompok, hanya dua unsur yang tidak berpengaruh terhadap dinamika kelompok, yaitu unsur tujuan dan tekanan kelompok. Sementara itu, dari enam unsur dinamika yang berpengaruh terhadap dinamika kelompok, unsur fungsi tugas memiliki pengaruh yang paling kuat terhadap dinamika kelompok tani.
\end{abstract}

Kata kunci: kelompok tani, dinamika kelompok

\section{Pendahuluan}

Peran sektor pertanian dalam pembangunan Indonesia masih sangat besar dan potensi pertanian Indonesiajugamasihsangatbesaruntukdikembangkan, namun pada kenyataannya, sektor pertanian masih memiliki banyak kendala dalam pengembangannya, bukan hanya dari sudut teknologinya semata, tetapi juga dari sudut manusianya, yaitu para petani itu sendiri. Sehubungan dengan itu, pengembangan dan peningkatan kompetensi petani perlu senantiasa ${ }^{1}$ Korespondensi penulis

E-mail: intadamanik@ymail.com dilakukan agar petani menjadi petani yang bukan hanya sebagai objek pembangunan tetapi sebagai subjek pembangunan.

Menurut Slamet (2003), pertanian selalu penuh dengan tantangan dan kemungkinan, dan karenanya para petani harus dikembangkan agar secara bertahap memiliki kemampuan intelektual yang meningkat, perbendaharaan informasi yang cukup, dan mampu merencanakan serta memutuskan sesuatu yang dianggap terbaik untuk dirinya. Undang-undang No.16/2006 tentang Sistem Penyuluhan Pertanian, Perikanan, dan 
Kehutanan menyebutkan bahwa diperlukan sumberdaya manusia (termasuk petani) yang berkualitas, andal, serta berkemampuan manajerial, kewirausahaan, dan organisasi bisnis sehingga bersama-sama dengan pelaku pembangunan pertanian, perikanan, dan kehutanan lainnya mampu membangun usaha dari hulu sampai dengan hiliryang berdaya saing tinggi dan berperanserta melestarikan hutan dan lingkungan hidup sejalan denganprinsip pembangunan berkelanjutan.

Kemajuan di bidang teknologi informasi juga menuntut kesiapan para petani menjadi pengguna (uset) dari teknologi tersebut misalnya gagasan menggunakan cyber extension, sebagai salah satu mekanisme pengembangan jaringan komunikasi informasi pembangunan pertanian yang terprogram secara efektif (Sumardjo, 2010). Dengan sistem ini, masalah keterlambatan informasi sampai ke petani akan teratasi, namun petani tidak lagi bersifat pasif, tetapi aktifmencari informasi yang dibutuhkannya. Semua ini membutuhkan partisipasi aktif dari para petani dan partisipasi dapat terjadi jika petani memiliki kemampuan, kemauan, dan kesempatan berpartisipasi. Salah satu cara yang telah lama digunakan untuk menggalakkan partisipasi petani dalam pembangunan dan untuk mengembangkan petani adalah dengan cara membentuk kelompokkelompok tani.

Kelompok tani dapat tumbuh dan berkembang di kalangan para petani Indonesia karena pada dasarnya masyarakat Indonesia dikenal sebagai masyarakat yang suka bekerjasama, tolong-menolong, bergotong-royong dan memiliki kepedulian yang tinggi satu dengan lainnya. Pada kenyataannya, tidak semua kelompok tani berkembang sesuai harapan, malah tidak sedikit kelompok tani yang bubar atau hanya tinggal nama. Bila digunakan ukuran kelas kemampuan kelompok tani, tidaksedikit kelompok tani yang sudah lama terbentuk namun masih pada kelas Pemula dan Lanjut. Hal ini tentu memprihatinkan sekaligus menjadi tantangan bagi pihak-pihak yang terkait dengan pembangunan pertanian.

Salah satu hal yang perlu diperhatikan dalam pengembangan kelompok tani adalah dinamika kelompok tani. Dinamika kelompok dapat diartikan sebagai kekuatan-kekuatan yang ada di dalam kelompok tersebut yang mengakibatkan kelompok secara efektifdapat mencapai tujuannya. Kelompok tani seharusnya menjadi kelompok yang dinamis sehingga dapat menjadi alat bagi para anggotanya untuk mencapai tujuan, baik tujuan pribadi maupun tujuan kelompok (karena dalam kehidupan berkelompok, tujuan pribadi harus searah dengan tujuan kelompok).

Ada sembilan unsur yang mempengaruhi dinamika suatu kelompok secara psikologis, yaitu: (1) tujuan kelompok, (2) struktur kelompok, (3) fungsi tugas, (4) pembinaan dan pemeliharaan kelompok, (5) kesatuan/kekompakan kelompok, (6) suasana (atmosfir) kelompok, (7) tekanan kelompok, (8) efektivitas kelompok, dan (9) maksud tersembunyi. Kesembilan unsur ini saling terkait satu sama lain dan selalu bergerak sesuai dengan keadaan kelompok.

Penentuan kelas-kelas kelompok tani oleh Departemen Pertanian dilakukan dengan menggunakan lima jurus yang merupakan gabungan dari 10 jurus sebelumnya. Adapun kelima jurus tersebut sesuai dengan SK Mentan No. 41/Kpts/OT.210/1992 adalah sebagai berikut: (1) kemampuan merencanakan kegiatan untuk meningkatkan produktivitas usahatani (termasuk pasca panen dan juga analisis usaha tani) dengan menerapkan rekomendasi yang tepat dan memanfaatkan sumberdaya alam secara optimal, (2) kemampuan melaksanakan dan menaati perjanjian dengan pihak lain, (3) kemampuan memupuk modal dan memanfaatkannya secara rasional, (4) kemampuan meningkatkan hubungan yang melembaga antara kelompok dengan KUD, dan juga (5) kemampuan menerapkan teknologi dan memanfaatkan informasi serta kerjasama kelompok yang dicerminkan oleh tingkat produktivitas dari usahatani anggota kelompok. Di Kabupaten Serang, tahun 2009 terdapat sejumlah 1.661 kelompok tani yang tersebar di 28 kecamatan dengan perincian 397 kelompok kelas Pemula, 672 kelompok kelas Lanjut, 439 kelompok kelas Madya, dan 153 kelompok kelas Utama.

Khusus di Desa Pulokencana terdapat delapan kelompok tani dengan perincian empat kelompok tergolong kelas Pemula, tiga diantaranya terbentuk tahun 2009 dan satu kelompok terbentuk tahun 2008; satu kelompok kelas Lanjut, satu kelompok kelas Madya, dan dua kelompok kelas Utama. Kelompok yang tergolong kelas Lanjut, Madya dan Utama seluruhnya terbentuk pada tahun 1982. Berdasarkan kelas-kelas kemampuan kelompok tersebut, terlihat bahwa kelompok tani yang lebih tua memiliki kelas kemampuan yang lebih tinggi dibandingkan kelompok yang lebih muda, meskipun diantara kelompok yang berusia tua (dibentuk tahun 1982) 
juga terjadi perbedaan kelas kelompok.

Apabila kelas kemampuan kelompok tani dipandang sebagai tingkat perkembangan kelompok tani, maka pencapaian kelas itu seharusnya tidak terlepas dari kedinamikaan kelompok tersebut. Artinya, harus ada perbedaan kedinamikaan diantara kelompok yang memiliki perbedaan kelas kemampuan sehingga dapat dikatakan bahwa kelompok yang lebih tua lebih dinamis dibandingkan dengan kelompok yang lebih muda. Apakah ini selamanya memang demikian? Apakah faktor kedinamikaan kelompok tani memang selamanya berkaitan dengan kelas kemampuan kelompok tersebut? Sehubungan dengan hal tersebut, penelitian ini dimaksudkan untuk meneliti kedinamikaan kelompok tani diantara kelompok tani kelas Utama (Banyu Mukti) dan kelompok tani kelas Pemula (Banjar Tani) dengan menggunakan sembilan unsur dinamika kelompok tani.

Berdasarkanuraian tersebut, maka permasalahan yang ingin diteliti dalam penelitian ini adalah: (1) bagaimanakah tingkat dinamika kelompok tani Banyu Mukti dan Banjar Tani? (2) faktor-faktor apakah yang mempengaruhi dinamika kelompok tani Banyu Mukti dan Banjar Tani? (3) apakah dinamika kelompok tani Banyu Mukti dan Banjar Tani sejalan dengan kelas kemampuan kelompok tersebut?, dan (4) bagaimanakah strategi meningkatkan dinamika kelompok tani Banyu Mukti dan Banjar Tani?

Mengacu kepada permasalahan tersebut, maka tujuan penelitian ini adalah:

(1) mengkaji tingkat dinamika kelompok tani Banyu Mukti dan Banjar Tani, (2) menganalisis faktorfaktor yang mempengaruhi dinamika kelompok tani Banyu Mukti dan Banjar Tani, (3) menganalisis keterkaitan antara dinamika kelompok tani dengan kelas kemampuan kelompok tani tersebut, dan (4) menemukan strategi untuk meningkatkan dinamika kelompok Banyu Mukti dan Banjar Tani.

Kelompok dapat diartikan sebagai kumpulan yang terdiri dari dua atau lebih individu yang saling berinteraksi satu sama lain dalam ikatan yang saling mempengaruhi untuk mencapai tujuan bersama (Cartwright dan Zander, 1968; Slamet, 1978; Kartono, 1994). Dengan pengertian ini, dapat dimengerti alasan individu untuk memasuki kelompok, yaitu karena kelompok bermanfaat bagi individu-individu yang menjadi anggotanya. Sebagai unit sosial, kelompok memiliki ciri-ciri: (a) memiliki ikatan yang nyata,

(b) memiliki interaksi dan interrelasi sesama anggotanya,

(c) memiliki struktur dan pembagian tugas yang jelas,

(d) memiliki kaidah-kaidah atau norma-norma tertentu yang disepakati bersama, dan

(e) memiliki keinginan dan tujuan bersama (Mardikanto, 1993).

Ciri-ciri dari kelompok tersebut umumnya ditemukan pada kelompok-kelompok yang proses pembentukannya didasarkan atas keinginan anggotaanggotanya, yaitu karena adanya keinginan memadukan kekuatan yang ada pada setiap anggota kelompok untuk secara bersama-sama mengatasi kelemahan yang dihadapi. Sebaliknya, ciri-ciri kelompok seperti itu, jarang ditemukan pada kelompok-kelompok yang dasar pembentukannya bukan atas keinginan para anggotanya, dan terhadap kelompok-kelompok seperti ini, usaha yang perlu dilakukan adalah menumbuhkan ciri-ciri kelompok tersebut sehingga kelompok bukan hanya sebagai simbol semata.

Hal yang tidak dapat dilepaspisahkan dari kehidupan suatu kelompok adalah dinamika kelompok (Nneoyi et al., 2008; Leilani dan Hasan, 2006; Barham dan Clarence, 2009; Nicolopoulou et al., 2006; Redono, 2006). Setiap kelompok perlu menumbuhkan dan memelihara dinamika kelompoknya untuk mempercepat pencapaian tujuan kelompok tersebut. Dinamika kelompok merupakan kekuatan-kekuatan yang terdapat di dalam ataupun dilingkungan kelompok yang akan menentukan perilaku anggota-anggota dan perilaku kelompok tersebut untuk melaksanakan berbagai kegiatan demi tercapainya tujuan kelompok yang merupakan tujuan bersama. Dinamika kelompok dapat tercapai jika semua unsur yang membangun kelompok berinteraksi dengan baik, baik unsur di dalam kelompok itu sendiri maupun unsur-unsur di luar kelompok itu.

Secara psikologis, ada sembilan faktor yang merupakan situasi kelompok yang mempengaruhi dinamika kelompok tersebut, yaitu (Slamet, 1978; Mardikanto, 1993): (1) tujuan kelompok, yaitu sesuatu yang ingin dicapai oleh kelompok; (2) struktur kelompok, yaitu sesuatu yang mengatur interaksi dalam kelompok dalam rangka mencapai tujuan; (3) fungsi tugas, yaitu seperangkat tugas yang harus dilaksanakan oleh setiap anggota kelompok sesuai 
dengan kedudukannya dalam struktur kelompok tersebut; (4) pembinaan dan pemeliharaan kelompok, yaitu usaha untuk menjaga kehidupan kelompok; (5) kesatuan/kekompakan kelompok, yaitu komitmen dari seluruh anggota untuk menciptakan kekuatan kelompok; (6) suasana (atmosfir) kelompok, yaitu keadaan moral, sikap dan perasaan-perasaan yang umum terdapat dalam kelompok dalam wujud senang, gembira, murung, dan bersemangat; (7) tekanan kelompok, yaitu segala sesuatu yang dapat menimbulkan ketegangan dalam kelompok yang dapat berasal dari dalam atau dari luar kelompok; (8) efektivitas kelompok, yaitu keefektivan kelompok dalam mencapai tujuan kelompok yang terlihat dari produktivitas kelompok, moral dan kepuasan anggota kelompok; dan (9) maksud tersembunyi, yaitu program, tugas, atau tujuan-tujuan yang tidak disadari oleh para anggota kelompok karena berada di bawah permukaan, namun mem-pengaruhi mental dan kejiwaan orang-orang dalam kelompok yang selanjutnya akan mempengaruhi perilaku mereka.

Redono (2006) menemukan bahwa beberapa faktor eksternal yang mempengaruhi progresivitas (dinamika) kelompok tani antara lain peran PPL, peran pemerintah desa dan peran pedagang, sedangkan faktor-faktor internal yang mempengaruhi progresivitas kelompok tani antara lain wawasan petani tentang kemajuan kelompok, dorongan petani untuk mencapai keberhasilan kelompok, kepemimpinan kelompok dan kohesivitas kelompok. Hasil penelitian ini berbeda dengan temuan Nneoyi (2008) melalui penelitiannya pada kelompok wanita tani di Nigeria. Nneoyi menemukan 11 karakteristik dan sifat kelompok wanita tani di Nigeria yang mempengaruhi dinamika kelompok tersebut, yaitu: (1) suasana kelompok, (2) komunikasi kelompok, (3) partisipasi kelompok, (4) standar yang berlaku dalam kelompok, (5) kontrol sosial, (6) identitas kelompok, (7) pembagian peran, (8) besar kelompok, (9) evaluasi, (10) nilai-nilai komunitas, dan (11) harapan kelompok.

Berdasarkan dari beberapa uraian dinamika kelompok tersebut, dapat dikatakan bahwa dinamika kelompok dipengaruhi oleh faktor-faktor tertentu yang mengikat kelompok tersebut. Faktor-faktor ini tidak harus sama pada setiap kelompok karena setiap kelompok memiliki karakteristik yang berbeda satu dengan lainnya.

Metode Penelitian

Penelitian dilaksanakan di Desa Pulokencana Kecamatan Pontang Kabupaten Serang Provinsi
Banten. Desa Pulokencana ini dipilih sebagai lokasi penelitian karena desa ini merupakan salah satu desa yang ditentukan sebagai sentra produksi pangan di Kabupaten Serang Provinsi Banten. Disamping itu, Gapoktan di desa ini juga merupakan Gapoktan yang sering mendapat bantuan/program, diantaranya program PUAP dan FEATI.

Populasi dalam penelitian ini adalah seluruh kelompok tani yang ada di Desa Pulokencana yang berjumlah delapan kelompok. Selanjutnya dipilih dua kelompok tani secara sengaja, yaitu kelompok tani Banyu Mukti dan Banjar Tani untuk mewakili kelompok-kelompok tani. Pertimbangan memilih kedua kelompok tersebut adalah karena kedua kelompok tersebut memiliki beberapa ciri kelompok yang hampir sama, yaitu jumlah anggota dan luasan lahan, namun memiliki umur dan kelas kemampuan yang berbeda (kelas Utama dan Pemula). Mewakili setiap kelompok tani terpilih selanjutnya diambil 15 anggota secara acak sederhana kecuali untuk ketua kelompok tani dan pengurus yang ditentukan secara sengaja.

Data yang dikumpulkan meliputi data primer dan data sekunder. Pengumpulan data dilakukan melalui wawancara dengan berpedoman kepada kuesioner yang telah dipersiapkan sebelumnya. Data sekunder meliputi data-data pendukung yang bersumber dari instansi terkait, kepustakaan, laporanlaporan, dan sumber-sumber lain yang relevan. Disamping itu, dilakukan wawancara mendalam terhadap berbagai pihak seperti ketua kelompok tani, penyuluh pertanian lapangan setempat, dan petugas BPTP sebagai pendamping. Data hasil penelitian selanjutnya ditabulasi menurut variabelnya dan dianalisis menggunakan analisis regresi dengan Program Minitab Release 16.

\section{Hasil dan Pembahasan}

\section{Karakteristik Anggota Kelompok Tani Banyu Mukti dan Banjar Tani}

Hasil analisis data tentang karakteristik terpilih dari anggota kelompok tani sampel disajikan pada Tabel 1. Berdasarkan Tabel 1 terlihat bahwa secara umum karakteristik anggota kelompok tani Banyu Mukti tidak jauh berbeda dengan anggota kelompok Banjar Tani, namun untuk karakteristik umur, tingkat pendidikan, dan pengalaman berkelompok terlihat 
Tabel 1 Karakteristik Anggota Kelompok Tani (KT) Banyu Mukti dan Banjar Tani

\begin{tabular}{|c|c|c|c|c|c|}
\hline \multirow[b]{2}{*}{ No. } & \multirow[b]{2}{*}{ Karakteristik } & \multicolumn{2}{|c|}{ KT. Banyu Mukti } & \multicolumn{2}{|c|}{ KT. Banjar Tani } \\
\hline & & $\begin{array}{c}\text { Jml. } \\
\text { (Orang) }\end{array}$ & Persen $(\%)$ & $\begin{array}{c}\text { Jml. } \\
\text { (Orang) }\end{array}$ & $\begin{array}{c}\text { Persen } \\
(\%)\end{array}$ \\
\hline \multirow[t]{6}{*}{1.} & Umur (Thn) & & & & \\
\hline & $\leq 42$ & 4 & 26,67 & 6 & 40,00 \\
\hline & $>42-49$ & 3 & 20,00 & 4 & 26,67 \\
\hline & $>49$ & 8 & 53,33 & 5 & 33,33 \\
\hline & Interval & $40-56$ & & $36-55$ & \\
\hline & Rata-rata & 48,2 & & 45 & \\
\hline \multirow[t]{4}{*}{2.} & Tingkat Pendidikan & & & & \\
\hline & SD & 11 & 73,33 & 7 & 46,67 \\
\hline & SLTP & 4 & 26,67 & 8 & 53,33 \\
\hline & SLTA & 0 & & 0 & 0,00 \\
\hline \multirow[t]{6}{*}{3.} & Pengalaman Berkelompok (Thn) & & & & \\
\hline & $\leq 14$ & 1 & 6,67 & 5 & 33,33 \\
\hline & $>14-24$ & 5 & 33,33 & 4 & 26,67 \\
\hline & $>24$ & 9 & 60,00 & 6 & 40,00 \\
\hline & Interval & $6-33$ & & $5-28$ & \\
\hline & Rata-rata & 24,8 & & 18,70 & \\
\hline \multirow[t]{6}{*}{4.} & Luas Lahan (ha) & & & & \\
\hline & $\leq 1,00$ & 8 & 53,33 & 13 & 86,67 \\
\hline & $>1,00-1,50$ & 2 & 13,33 & 1 & 6,66 \\
\hline & $>1,50$ & 5 & 33,33 & 1 & 6,66 \\
\hline & Interval & $0,33-2,0$ & & $0,5-2,0$ & \\
\hline & Rata-rata & 1,25 & & 0,89 & \\
\hline \multirow[t]{5}{*}{5.} & Status Lahan & & & & \\
\hline & -Pemilik & 4 & 26,67 & 3 & 20,00 \\
\hline & -Penggarap & 9 & 60,00 & 12 & 80,00 \\
\hline & -Penyewa \& Penggarap & 1 & 6,66 & 0 & 0,00 \\
\hline & -Pemilik \&Penggarap & 1 & 6,66 & 0 & 0.00 \\
\hline \multirow[t]{6}{*}{6.} & Jumlah tanggungan (org) & & & & \\
\hline & $\leq 3$ & 2 & 13,33 & 6 & 40,00 \\
\hline & $4-5$ & 11 & 73,33 & 8 & 53,33 \\
\hline & $>5$ & 2 & 13,33 & 1 & 6,67 \\
\hline & Interval & $3-6$ & & $2-6$ & \\
\hline & Rata-rata & $4,53=5$ & & $3,8=4$ & \\
\hline
\end{tabular}

sedikit berbeda. Anggota kelompok tani Banyu Mukti sebagian besar berumur di atas 49 tahun dengan tingkat pendidikan mayoritas hingga SD, dan pengalaman berkelompok lebih dari 24 tahun; sedangkan anggota kelompok tani Banjar Tani tingkat umur menyebar hampir merata pada interval $36-55$ tahun dengan tingkat pendidikan dominan SLTP, namun pengalaman berkelompok rata-rata lebih pendek. Keadaan ini disebabkan anggota kelompok tani Banjar Tani memang tergolong lebih muda dibandingkan anggota kelompok tani Banyu Mukti. Pengalaman berkelompok anggota kelompok Banjar Tani yang hampir menyamai anggota kelompok Banyu Mukti disebabkan kelompok Banjar Tani merupakan pecahan dari kelompok Banyu Mukti. Pemecahan kelompok Banyu Mukti dilakukan pada tahun 2009 karena berbagai alasan, diantaranya jumlah anggota yang dipandang terlalu banyak dengan 
Tabel 2 Keragaan Dinamika Kelompok Tani Banyu Mukti dan Banjar Tani

\begin{tabular}{|c|c|c|c|c|c|c|}
\hline \multirow{3}{*}{ No } & \multirow{3}{*}{ Unsur Dinamika Kelompok } & \multirow{3}{*}{$\begin{array}{c}\text { Skor } \\
\text { Maksimum }\end{array}$} & \multicolumn{4}{|c|}{ Capaian Skor Rata-rata*) } \\
\hline & & & \multicolumn{2}{|c|}{$\begin{array}{c}\text { KT. Banyu } \\
\text { Mukti }\end{array}$} & \multicolumn{2}{|c|}{$\begin{array}{c}\text { KT. Banjar } \\
\text { Tani }\end{array}$} \\
\hline & & & Skor & $\%$ & Skor & $\%$ \\
\hline 1. & Tujuan Kelompok & 15 & 13 & 86,67 & 14 & 93,33 \\
\hline 2. & Struktur Kelompok & 20 & 16 & 80.00 & 17 & 85,00 \\
\hline 3. & Fungsi Tugas & 25 & 17 & 68,00 & 18 & 72,00 \\
\hline 4. & Pembinaan dan Pemeliharaan Kelompok & 18 & 15 & 83,33 & 15 & 83,33 \\
\hline 5. & Kekompakan Kelompok & 20 & 13 & 65,00 & 13 & 65,00 \\
\hline 6. & Suasana Kelompok & 15 & 9 & 60,00 & 9 & 60,00 \\
\hline 7. & Tekanan Kelompok & 14 & 10 & 71,43 & 10 & 71,43 \\
\hline \multirow[t]{2}{*}{8.} & Keefektivan Kelompok & 20 & 14 & 70,00 & 13 & 65,00 \\
\hline & Dinamika & 147 & 107 & 72,79 & 109 & 74,15 \\
\hline
\end{tabular}

Keterangan: *) = angka pembulatan

areal persawahan yang terlalu menyebar. Pemecahan kelompok diharapkan dapat lebih meningkatkan efektivitas kelompok dan pengembangan petani anggotanya, baik pada kelompok Banyu Mukti maupun kelompok Banjar Tani.

\section{Dinamika Kelompok}

Hasil analisis tentang dinamika kelompok tani Banyu Mukti dan Banjar Tani menunjukkan tingkat dinamika kelompok tani tersebut dan pencapaian setiap unsur dinamika kelompok seperti pada Tabel 2. Tabel 2 menunjukkan bahwa capaian skor dinamika kelompok Banyu Mukti (72,79\%) lebih rendah dibandingkan kelompok Banjar Tani (74,15\%), dan jika dikategorikan ke dalam kelas menurut interval skor maksimum dan minimum dinamika dalam kelompok tersebut (31-147), maka dinamika kelompok Banjar Tani termasuk dalam kategori tinggi sedangkan kelompok Banyu Mukti tergolong sedang, meskipun hanya terpaut dua angka. Unsur yang berbeda nilainya diantara kedua kelompok tersebut adalah unsur tujuan kelompok, struktur kelompok, fungsi tugas, dan keefektivan kelompok.

Jumlah tanggungan akan berpengaruh positif terhadap dinamika kelompok dapat dijelaskan dalam kaitannya dengan tanggungjawab kepala keluarga atas kebutuhan rumah-tangganya. Kepala keluarga yang memiliki tanggungan yang lebih banyakakan lebih giat dalam kegiatan-kegiatan kelompok dengan tujuan dapat membantunya dalam berusahatani yang selanjutnya dapat meningkatkan produktivitas usahataninya.

Disamping itu, keaktifan dalam kelompok tani juga membuka peluang untuk ditunjuk mengikuti kegiatan lain, seperti pelatihan-pelatihan di tingkat gapoktan mewakili kelompok tani. Berdasarkan Tabel 1 dapat dilihat bahwa anggota kelompok tani Banjar Tani memiliki keragaman yang lebih tinggi dalam hal jumlah tanggungan $(\leq 3$ dan $4-5$ orang) dibandingkan pada kelompok Banyu Mukti yang cenderung homogen (4 - 5 orang) sehingga anggota kelompok tani Banjar Tani yang lebih aktif di kelompok tani juga lebih banyak dibandingkan anggota kelompok Banyu Mukti.

Luas lahan berpengaruh negatif terhadap dinamika kelompok tani, artinya semakin luas areal atau lahan petani, semakin rendah dinamika kelompok taninya. Petani dengan luas lahan yang lebih besar akan membutuhkan waktu yang lebih banyak untuk mengelola lahan tersebut sehingga keaktifan pada kegiatan kelompok tani menjadi berkurang. Pada Tabel 1 terlihat bahwa luas lahan usahatani anggota kelompok Banyu Mukti lebih bervariasi dibandingkan kelompok Banjar Tani yang cenderung lebih homogen.

\section{Pengaruh Karakteristik Kelompok, Karakteristik Pemimpin dan Faktor Eksternal Kelompok terhadap Dinamika Kelompok Tani}

Hasil analisis terhadap karakteristik kelompok, karakteristik pemimpin (ketua) kelompok dan faktor eksternal kelompok menghasilkan keragaan seperti pada Tabel 3. Berdasarkan Tabel 3 terlihat bahwa faktor 
Tabel 3 Karakteristik Pemimpin dan Kelompok serta Keragaan FaktorEksternal Kelompok Tani (KT)

\begin{tabular}{|c|c|c|c|}
\hline No & Uraian & KT. Banyu Mukti & KT. Banjar Tani \\
\hline \multirow[t]{6}{*}{ I. } & Karakteristik Pemimpin & & \\
\hline & 1. Umur (Thn) & 51 & 49 \\
\hline & 2. Pendidikan Formal & SLTP & SLTP \\
\hline & 3. Pengalaman Memimpin (Thn) & 28 & 1 \\
\hline & 4. Motivasi Memimpin & Tinggi & Tinggi \\
\hline & 5. Penerimaan Anggota & Baik $(80 \%)$ & Baik $(85 \%)$ \\
\hline \multirow[t]{3}{*}{ II. } & Karakteristik Kelompok Tani & & \\
\hline & 1. Dasar Pembentukan Kelompok & $\begin{array}{c}\text { Kerjasama dan pengembangan } \\
\text { petani }\end{array}$ & $\begin{array}{c}\text { Kerjasama dan pengembangan } \\
\text { petani }\end{array}$ \\
\hline & 2. Umur Kelompok (Thn) & 28 & 2 \\
\hline \multirow[t]{5}{*}{ III. } & Keragaan Faktor Eksternal Kelompok Tani & & \\
\hline & 1. Frekuensi Interaksi dengan PPL & Tinggi & Sedang \\
\hline & 2. Pelatihan & Sedang & Sedang \\
\hline & 3. Bantuan dana & Sedang & Sedang \\
\hline & DINAMIKA KELOMPOK & Sedang & Tinggi \\
\hline
\end{tabular}

pengalaman memimpin dan umur kelompok sangat berbeda antara kelompok Banyu Mukti dan Banjar Tani, frekuensi interaksi dengan PPL. Kelompok Banjar tani merupakan kelompok hasil pengembangan dari Banyu Mukti sehingga dasar pembentukan kelompok juga tidak berbeda dengan kelompok Banyu Mukti, yaitu untuk lebih mengembangkan petani. Usia kelompok yang lebih tua juga menyebabkan kelompok Banyu Mukti lebih sering berinteraksi dengan PPL karena ketua kelompok Banyu Mukti juga menjadi Ketua Gapoktan yang sering mendapat program bantuan dari Pemerintah. Dengan demikian, frekuensi berinteraksi dengan PPL menjadi lebih tinggi dibandingkan dengan kelompok Banjar Tani yang lebih muda. Dikaitkan dengan dinamika kelompok, hal yang menarik justru dinamika kelompok Banjar Tani lebih tinggi dibandingkan dengan Banyu Mukti. Hal ini berarti pengalaman memimpin ketua kelompok, umur kelompok, dan frekuensi interaksi dengan PPL yang lebih tinggi tidak mempengaruhi dinamika kelompok. Hal ini berlawanan dengan Redono (2006) yang menyatakan bahwa PPL berpengaruh terhadap dinamika kelompok tani.

\section{Pengaruh Unsur-unsur Dinamika Kelompok terhadap Dinamika Kelompok Tani}

Hasil analisis menunjukkan bahwa dari delapan unsur dinamika kelompok yang dianalisis, ternyata unsur tujuan dan tekanan kelompok tidak berpengaruh terhadap dinamika kelompok. Dengan demikian hanya ada enam unsur yang berpengaruh, antara lain: (1) struktur kelompok, (2) fungsi tugas, (3) pembinaan dan pemeliharaan kelompok, (4) kekompakan kelompok, (5) suasana kelompok, dan (6) keefektivan kelompok. Hal ini sejalan dengan hasil penelitian Nneoyi (2008). Analisis selanjutnya terhadap keenam unsur ini menunjukkan bahwa unsur fungsi tugas memiliki pengaruh terbesar terhadap dinamika kelompok yang ditunjukkan dengan nilai $\mathrm{R} 2=79,47 \%$, artinya 79,47\% dinamika kelompok tani Banyu Mukti dan Banjar Tani dipengaruhi oleh unsur fungsi tugas dan 20,53\% dipengaruhi oleh lima unsur lainnya, yaitu suasana kelompok 11,10\%, kekompakan kelompok 3,39\%, pembinaan dan pemeliharaan kelompok 2,34\%, keefektivan kelompok 1,30\%, dan struktur kelompok 1,24\%.

Fungsi tugas memiliki pengaruh terbesar terhadap dinamika kelompok karena kelompok Banyu Mukti dan Banjar Tani memang tergabung dalam Gapoktan yang seringkali mendapat bantuan berupa program seperti PUAP dan FEATI. Sehubungan dengan itu, dibutuhkan fungsi koordinasi, diseminasi informasi dalam kelompok, fungsi penjelasan, dan pihak-pihak yang berani memulai inisiasi yang semuanya terangkum dalam unsur fungsi tugas. Adapun persamaan fungsi dinamika kelompok yang diperoleh adalah: $\mathrm{Y}=109+7,23 \mathrm{X} 1+3,22 \mathrm{X} 2+$ $2,19 \mathrm{X} 3+1,52 \mathrm{X} 4+1,41 \mathrm{X} 5+1,27 \mathrm{X} 6$; dimana $\mathrm{X} 1=$ fungsi tugas, $\mathrm{X} 2$ = suasana kelompok, $\mathrm{X} 3$ 
= kekompakan kelompok, X4 = pembinaan dan pemeliharaan kelompok, X5 = keefektivan kelompok, dan X6 = struktur kelompok.

\section{Hubungan Dinamika Kelompok dengan Kelas Kemampuan Kelompok Tani}

Berdasarkan hasil analisis tentang dinamika kelompok Banyu Mukti dan BanjarTani dan dikaitkan dengan kelas kemampuan kelompok tani maka dapat disimpulkan bahwa kelas kemampuan kelompok tani pada kenyataannya tidak berhubungan dengan tingkat dinamika kelompok tani. Kelompok Banyu Mukti tergolong ke dalam kelas Utama, sedangkan Banjar Tani termasuk ke dalam kelas Pemula, padahal dari sudut dinamika kelompok ternyata kelompok Banjar Tani lebih dinamis. Kenyataan ini disebabkan penilaian kelas kemampuan kelompok tani di Desa Pulaukencana ternyata tidak didasarkan pada keadaan kelompok tani, tetapi terfokus kepada penilaian ketua kelompok tani. Kelompok tani yang memiliki ketua kelompok yang dinilai aktif oleh PPL dalam kaitannya dengan pelaksanaan suatu program, memiliki akses yang lebih lancar kepada pihak-pihak yang terkait dengan program di bidang pertanian, serta umur kelompok tani yang lebih tua cenderung dinilai memiliki kelas yang lebih tinggi seperti halnya terjadi pada kelompok Banyu Mukti. Kenyataan lain adalah kelas kemampuan kelompok tani tidak pernah diturunkan meskipun keadaan kelompok menurun untuk mencegah terjadinya gangguan psikologis anggota kelompok tani. Itulah sebabnya kelompok tani Banyu Mukti selalu berada pada kelas Utama.

\section{Strategi Peningkatan Dinamika Kelompok Tani}

Meskipun pada kenyataannya tingkat dinamika kelompok tidak menjadi penilaian dalam menentukan kelas kemampuan kelompok tani, namun dinamika kelompok tetap penting untuk dijaga dan ditingkatkan oleh kelompok tani, khususnya bagi kelompok yang masih muda di Desa Pulokencana. Hasil analisis menunjukkan bahwa unsur fungsi tugas berpengaruh sangat kuat terhadap dinamika kelompok, disamping itu faktor jumlah beban tanggungan dan luas lahan juga berpengaruh terhadap dinamika kelompok.

Berdasarkan hal tersebut, strategi yang dapat dilakukan untuk meningkatkan dinamika kelompok tani adalah dengan cara memperbaiki pelaksanaan fungsi tugas, meningkatkan rasa tanggung jawab anggota kelompok tani terhadap kelompok tani, serta menggerakkan kerjasama dalam kelompok. Unsur fungsi tugas dapat ditingkatkan melalui peningkatan usaha dalam mencari informasi yang dibutuhkan oleh kelompok tani, misalnya informasi tentang harga pasar dan musim panen padi di daerah lain dalam wilayah Provinsi Banten yang seringkali menjatuhkan harga jual gabah/beras para petani. Demikian pula informasi tentang sarana produksi, pelatihan-pelatihan dan hal-hal lain sesuai kebutuhan petani.

Rasatanggungjawabpenting ditingkatkankarena terbukti rasa tanggungjawab akibat jumlah tanggungan yang lebih besar dapat meningkatkan keaktivan anggota dalam berkelompok. Rasa tanggungjawab anggota dapat ditingkatkan melalui pemberian kepercayaan kepada anggota untuk mewakili anggota ke luar kelompok secara bergiliran sehingga setiap anggota merasa diberikan tanggungjawab. Disamping itu dapat pula dilakukan dengan jalan memberikan kepercayaan kepada anggota secara bergiliran untuk memimpin pertemuan kelompok, dan sebagainya. Hal ini juga sekaligus dapat meningkatkan partisipasi anggota dalam kelompok.

Kerjasama antar anggota perlu ditingkatkan untuk menumbuhkan kembali semangat gotong royong sebagai warisan budaya bangsa Indonesia. Hal ini untuk mencegah ketidakaktivan anggota kelompok pada kegiatan kelompok karena memiliki lahan yang lebih luas sehingga sebagian besar waktunya tersita untuk mengelola lahan usahanya. Dengan adanya kerjasama antar anggota, keadaan tersebut dapat teratasi, tentu saja dengan aturanaturan kerjasama yang disepakati oleh semua anggota.

Hal lain yang dapat dilakukan untuk meningkatkan dinamika kelompok tani sesuai hasil analisis adalah meningkatkan kualitas suasana kelompok dengan menciptakan hal-hal yang dapat membangkitkan semangat anggota kelompok; meningkatkan kekompakan kelompok melalui penumbuhan rasa saling memiliki diantara anggota, menumbuhkan sikap toleransi dalam kelompok, dan rasa bangga sebagai anggota kelompok.

Pemberlakuannormaatauaturankelompokperlu dilaksanakan sebagai bentuk kontrol terhadap perilaku anggota dan salah satu ciri kelompok (Mardikanto, 
1993), sehingga setiap anggota bertanggungjawab atas perilakunya terhadap kelompoknya sesuai dengan hak dan kewajiban anggota dalam Anggaran Dasar/ Anggaran Rumah Tangga (AD/ART). Sehubungan dengan itu, setiap kelompok sebaiknya memiliki AD/ ART yang pada kenyataannya belum dimiliki oleh kelompok Banyu Mukti dan Banjar Tani. Disamping itu, mendorong kelompok untuk melengkapi struktur kelompok serta memiliki kepemimpinan yang efektif juga perlu dilakukan.

\section{Kesimpulan}

Dinamika kelompok Banjar Tani tergolong tinggi, sedangkan dinamika kelompok Banyu Mukti tergolong sedang. Kedinamikaan kelompok tani ini dipengaruhi oleh beberapa faktor, yaitu faktor jumlah tanggungan dan luas lahan, faktor umur pemimpin dan umur kelompok dimana kelompok dengan umur pemimpin dan umur kelompok yang lebih muda justru lebih dinamis, dan penerimaan anggota terhadap pemimpin kelompok dimana pemimpin yang lebih diterima oleh anggota memiliki dinamika kelompok yang lebih tinggi.

Unsur-unsur yang paling kuat mempengaruhi dinamika kelompok adalah fungsi tugas diikuti secara berturut-turut oleh suasana kelompok, kekompakan kelompok, pembinaan dan pemeliharaan kelompok, keefektivan kelompok, dan juga struktur kelompok. Pembenahan terhadap unsur-unsur dinamika kelompok penting dilakukan meskipun pada kenyataannya tidak ada keterkaitan antara dinamika kelompok tani dengan kelas kemampuan kelompok tani sebab penilaian kelas kemampuan kelompok tani yang dilakukan di Desa Pulokencana tidak didasarkan pada dinamika kelompok tani, melainkan semata-mata hanya penilaian terhadap ketua kelompok tani saja. Umur ketua kelompok Banjar Tani yang lebih muda didukung oleh penerimaan anggota atas dirinya sebagai ketua kelompok yang lebih besar dibandingkan penerimaan anggota kelompok Banyu Mukti atas ketuanya mampu meningkatkan dinamika kelompok Banjar Tani.

Strategi peningkatan dinamika kelompok Banyu Mukti dan Banjar Tani adalah dengan meningkatkan keenam unsur dinamika yang memiliki pengaruh terhadap dinamika kelompok dan memperkuat unsur tujuan dan tekanan kelompok yang belum menunjukkan pengaruh terhadap dinamika kelompok. Tindakan nyata yang dapat dilaksanakan kelompok untuk melaksanakan strategi peningkatan dinamika tersebut antara lain menyusun AD/ART, memberikan kepercayaan kepada anggota secara bergiliran untuk tugas-tugas di dalam dan di luar kelompok, memperkuat semangat kerjasama dan toleransi antar anggota.

\section{Daftar Pustaka}

Barham J, Clarence C. 2009. Collective Action Initiatives to Improve Marketing Performance: Lessons from Farmer Groups in Tanzania. Elsevier: Food Policy 34 (2009) 53-59.

Cartwright D, Zander A. 1968. Group Dynamics: Research and Theory. New York: Herper and Row Publisher.

Kartono K. 1994. Pemimpin dan Kepemimpinan: Apakah Pemimpin Abnormal Itu? Jakarta: PT. RajaGrafindo Persada.

Leilani A, OD Subhakti H. 2006. Analisis Dinamika Kelompok pada Kelompok Tani Mekarsari Desa Purwasari Kecamatan Dramaga Kabupaten Bogor.Jurnal Penyuluhan Pertanian Vol. 1 No. 1.

Mardikanto T. 1993. Penyuluhan Pembangunan Pertanian. Surakarta: Sebelas Maret University Press.

Nicolopoulou K., Mitja K., Andre C. 2006. How to Address Group Dynamics in Virtual Worlds. Springer-Verlag London Limited.

Nneoyi IO, MN Henry, AM Walter, dan EE Ebingha. 2008. Group Dynamics and Technology Use among Female Cassava Farmers in Akpabuyo Local Government Area, Cross River State, Nigeria. Agricultural Journal 3 (4): 292298,2008. ISSN: 1816-9155. (C) medwell Journals.

Redono C. 2006. Beberapa Faktor yang Berpegaruh Terhadap Progresivitas Kelompok Tani Lahan Pantai di Kabupaten Kulon Progo.Jurnal Ilmuilmu Pertanian.Volume 2, Nomor 1, Juli 2006.

Slamet M. 1978. Penyuluhan Pertanian: Kumpulan Bahan Bacaan. Bahan Ceramah pada Pekan Orientasi Kepemimpinan Dokter 1978. Diselenggarakan oleh Ikatan Universitas Indonesia Cabang Fakultas Kedokteran di Jakarta.

Slamet M. 2003. Membentuk Pola Perilaku Manusia Pembangunan. Penyunting Ida Yustina \& Adjat 
Jurnal Penyuluhan, Maret 2013 Vol. 9 No. 1

Sudrajat.Bogor: IPB Press.

Sumardjo, Lukman MB, Retno SHM. 2010. Cyber

Extension: Peluang dan Tantangan dalam

Revitalisasi Penyuluhan Pertanian. Bogor: IPB

Press. 